\title{
Environmental Factors and Human Resource Management in Local Government Administration in Nigeria
}

\author{
Goddey Wilson \\ http://dx.doi./org/10.4314/ujah.v20i2.7
}

\begin{abstract}
Human resource management is the mobilisation of available human resource in the organization to achieve the organizational goals. Human resource management activities are not devoid of challenges in any organization, including Local Government Councils in Nigeria; hence, this study identified such challenges as environmental factors and classified it as internal and external environmental factors affecting human resource management in Nigerian Local Governments. These factors were identified on account of the observed irregularities in human resource management policies and practice in the Local Government service. This study therefore aims at examining the environmental factors affecting human resource management in Nigerian local governments between 2010-2018. Data were collected from observations, interviews and documented facts on the subject matter, while system theory was used to explain the interdependence of the various departments and its effects on human resource management in the Councils. The study findings identified poor capacity building and orientation, activities of trade unions, administrative policies and politics, capacity of the Council leadership, among others as internal factors; and political, social, legal, physical, etc., as part of the external environmental factors affecting human resource management in Nigerian Local Governments. The study concluded that the internal and external factors have significant effects on the human resource management and productivity of the Local Governments in Nigeria. This study
\end{abstract}


further made some recommendations on strategies to achieve effective human resource management in Nigerian Local Governments.

Keywords: Staff development, Local Government, environmental factors, human resource management, organizational productivity.

\section{Introduction}

Local Government is identified as the government nearest to the people, with the responsibility of developing the rural areas and their people. In Nigeria, this perspective is not different, as the local government is established as a third tier government with the objective of bringing development closer to the people (Wilson, 2015). Wilson (2013:136) holds that the Local Government system in Nigeria has undergone several reforms at different times, aimed at strengthening it to achieve its development objectives. Before the coming of the colonial masters, Nigeria had established traditional institutions in various communities with the responsibility of administering the affairs of the rural people. During colonialism, the British Government took advantage of these established traditional institutions and introduced the Native Administration system for effective administration. Abonyi (2010:89) add that the Native Administration, often referred to as Native Authority strengthened the various traditional institutions for service delivery in Nigeria.

Upon political independence in 1960, the Nigerian Government maintained the administrative structure, although with some innovations, which empowered the Regional Governments to administer the affairs of the traditional institutions. In 1976, Nigeria witnessed the emergence of formal Local Government as a distinct tier of government with drastic reforms in the operational activities of the government. The 1976 reforms was the first to 
Wilson: Environmental Factors and Human Resource Management in Local Government Administration in Nigeria

formally recognize local government as a third tier government with basic responsibility of developing the rural areas and people therein, thereby encouraging participatory democracy in the rural areas. Ever since, it has been one reform or the other aimed at repositioning the local government with necessary capacity and human resource management activities for adequate functioning of the Local Governments in Nigeria. Specifically, the Federal Military Government in 1988 introduced the Civil Service Reform aimed at professionalization of the local government service, leading to the creation of statutory departments such as Personnel, Finance and Supply, Works, Health etc. To ensure effectiveness of the service, various departments were designated to be manned by competent manpower leading to the creation of the offices of Secretary to the Local Government, Treasurer, Auditor-General for Local Government, and Local Government Service Commission with the authority to make and implement policies that will regulate human resource management activities in the Local Governments. The 1979 and 1999 Constitutions of Nigeria further recognized the Local Government as a third-tier government with necessary human resource management functions and powers to operate effectively in Nigeria. In that case, human resource management entails the application of human resource management policies and practices for the purpose of effective staff productivity and local government efficiency. Such human resource management activities include human resource planning, training, development, recruitment, deployment, staff appraisal, utilization and retirement in the local governments.

Notwithstanding the above reforms and provisions for effective human resource management in local governments, it appears the human resource management activities are facing some 
challenges. The study observed poor staff response to work, regular staff resistance to staff posting, staff inability to carry out their daily duties, low manpower base, poor staff utilization, among others as the perceived human resource management challenges in ocal Governments; and attributed these challenges to environmental factors affecting human resource management in Local Governments. These problems have attracted the attention of many scholars and practitioners on Local Government administration. The study objective therefore, is to identify and discuss the internal and external environmental factors affecting human resource management activities of local government administration in Nigeria within the period of 2010-2018. Observation, interview and documentary sources of data were used.

\section{Conceptual Discourse}

\section{Human Resource Management}

Human resource management is considered as both a field of study in academics and practice in bureaucratic organization. Its emergence is traced to the dynamics of European economy in the $18^{\text {th }}$ and $19^{\text {th }}$ centuries. Within the period, there was a shift on emphasis from the use of human beings as "products" of the organization to the use of human beings as "producers" of the needed products in the economy. This change in focus and value for human beings (organizational manpower) gave rise to the quest for management of the available manpower to enhance organizational productivity in Europe. Graffin (2007), Markle (1980) and Mark (2014) in their separate studies attributed the rise of human resource management to the outcome of the "Industrial Revolution", Fredrick Taylor's "Scientific Management" and effects of "World War 1 \& 11". These scholars further 
acknowledged the contributions of the works of Elton Mayo on "Hawthorne Studies", and Abraham Maslow "theory of needs" to the emergence of human resource management. Ever since, human resource management as a field of study and practice has witnessed tremendous changes at one point or the other due the changing social and economic activities in the industries.

Human resource management involves the management of workers in the workplace to enhance organizational productivity. Johnason (2009) and Collins \& Wood (2009) see human resource management as the duties carried out by the human resource department, particularly in the areas of human resource planning, training and development, recruitment and deployment, payment of benefits, utilization, retirement and effective industrial relations in the organization. These duties are important and determine the activities of the workers and operation of the organization

According to Ojo (1998), human resource management is the "designing and implementation of policies and all the practices that can assist in promoting efficient utilization of human resources". The scholar added that human resource management can be used interchangeably with manpower management, personnel administration, or personnel management and is centered on effective training, development, and utilization of the organizational workforce for functioning of the organization. Notable is the fact that these policies are made and carried out in the organization with the basic aim of attracting and retaining the workers to ensure optimal productivity. However, Nabaho \& Kiiza (2018) stated that the nature of administrative policies and politics of the local government affect the staff management and mobility in the Councils. In his perspective, Onah (2015) states that human resource management involves the process of obtaining the right 
caliber of staff, deploying them to the right work and maintaining the staff to enable the organization meet its goal. The implication is that the organization needs right quality staff to function, and therefore needs to set the process of obtaining them, deploying them to the right duties, maintaining the existing staff and create enabling working environment for the staff to operate. This will promote staff productivity and enhance organizational effectiveness. Ojo (1997) and Ojo (1998) acknowledged the above as vital activities of human resource management and added that staff motivation, staff appraisal and effective labour-management relations are needed to ensure effective staff performance and industrial peace in the workplace, including local governments.

Considering the above, we explain human resource management as the process of making and implementing human resource management policies in the organization, including local governments with the aim of effectively managing the available human resource to accomplish the organizational goals. The human resource management policies and practices are greeted with some challenges in Nigerian Local Governments. And such challenges are classified as internal and external environmental factors affecting human resource management in the 774 Local Governments in Nigeria.

\section{Theoretical Discourse \\ System Theory}

Scholars at different times and from different fields of study have discussed system theory to their understanding, ranging from studies on biological, environmental, pure sciences, to behavioural sciences. Historically, system theory has its root from the views of Aristotle on knowledge, who claimed that knowledge is derived from the understanding of the "whole" and not the "single parts" 
(Mele, Pels, \& Polese, 2010). A system is viewed as an "entity/whole" (organization) with internal and external environment, which determines the input and output dynamics of the entity/whole. Bertalanffy (1956) sees a system as a complex interaction of the elements that make up the whole. As a theory, it is interdisciplinary in nature, and is used in the study of biological, environmental, and social dynamics of human relations in the society. The theory was popularized by Ludwig Von Bertalanffy in his study on "general system theory" in 1950 (Bertalanffy,1950). Katz \& Kahn (1966) explain system theory as a theory that is concerned with the study of relationships, of structure, and of the interdependence of one unit on the other for smooth working. The main point of emphasis of the theory is on interaction and interdependence of the units to ensure the effectiveness of the whole. The justification is that the system theory is applicable to both studies on pure sciences and social sciences. In social sciences, it centers on human interactions and behaviourial activities in organizations. The interactions and activities of the staff are determined by the organizational policies and practices.

The usefulness of system theory to this study is in explanation of the local government as a system, where the various departments (units) interact and inter-depend on each other for the effectiveness of local governments in Nigeria. As a system, the local governments are bound by internal and external environments, which regulate its activities and human resource management policies and practices. Such environments include the economic, political, socio-cultural, technological, leadership factors, etc. The human resource activities of the local governments are carried out by Personnel (Administration) Department under the supervision of the State Local Government 
Service Commission. The implication is that the Administration Department is not an independent unit in the Council, and therefore, its human resource management activities are influenced by the activities of other interacting units and such enabling environments in the local government. Therefore, effectiveness of the Administration Department is a function of its interactions with other Departments in the local government and sectors in the state.

\section{Environmental Factors Affecting Human Resource Management in Local Government Administration in Nigeria} In discussing the environmental factors, emphasis will be based on internal and external environmental factors.

\section{Internal Environmental Factors}

Poor capacity building and orientation: The study noted that most of the local government workers are not adequately trained and developed to develop others, particularly their subordinates. Some of the staff are poorly-oriented and misinformed on the need for capacity building leading to their care free attitude to training and development programmes, even when they are opportune to participate in such trainings and development progrmmes. Agunyai (2015) adds that poor capacity building among most of the senior staff accounts for their inability to impact skill on their subordinates in the service, and creates human resource management challenge in the local governments. This challenge is attributed to the inability of Rivers State Local Government Service Commission to effectively carry out its human resource management policies and practice in the Councils, thereby accounting for poor capacity building in the Councils. 
The activities of trade unions: Notable among the trade unions operating in the local governments are Nigeria Union of Local Government Employees (NULGE), Medical and Health Worker Union of Nigeria (M\&HWUN), and National Association of Nigeria Nurses and Midwives (NANNM). These unions engage the local government management in regular industrial conflicts, culminating in strike actions. Within the period, staff does not participate in the administrative activities of the Councils, including staff training and development programmes. This affects negatively, the human resource management activities of the affected Council.

Information and Communication System in the Councils: The information dissemination and policy communication system in some Local Governments is poor and affects human resource management activities. In most cases, policy decisions of the Councils are not communicated to the staff properly, including staff development programme and posting to new units/stations. This deprives the affected staff the opportunity of participating in the development programme and reporting early to the new station.

Capacity of the Council leadership: Capacity of the Council leadership is explained within the context of the ability of the Executive Chairman and his/her cabinet, Legislative Leader and other functionaries of the Legislative Council, and Head of Administration and other Directors in the Council to carry out staff development and utilization in the Council. The capacity of the leadership determines the leadership style in the Local Government and affects staff development and utilization. Baikie (2002) and 
Omodia (2009) state that the willingness or otherwise of the leadership to approve and sponsor staff for development programme and utilizing the trained staff appropriately affects human resource management of the Local Governments in Nigeria.

Administrative policies and politics: For this study, administrative policies imply the bureaucratic policies and practice guiding the operation of Local Government service in Nigeria. As a service, bureaucracy is necessary to ensure administrative orderliness and efficiency, but in most cases, it results in a delay in processing, approving and mobilising the required staff for training, development and utilization. On the other perspective, the administrative politics entails the interplay of personal interest of the principal Local Government functionaries as against merit in making and implementing human resource management policies in the service. This affects staff selection process, training, planning and utilisation. Giddens (1986) corroborates with the above view and adds that bureaucratic delay and internal politics in the service affects the human resource management activities of the organization.

Management of Staff Data: Our interview with some principal staff of the Councils on staff numerical strength and deployment proves that such local governments have inadequate records of its staff. Although they credited it to incessant staff posting and reposting, mutilation of staff data, and delay in staff record update in the local governments. Okolie (2000) attributes the poor statistical data of local government staff to irregular activities of the Planning and Statistics Department leading to inadequate staff data of the local governments. Management of staff data affects 
Wilson: Environmental Factors and Human Resource Management in Local Government Administration in Nigeria

human resource planning, utilization and productivity in the local government service.

\section{External Environmental Factors}

Economic and fiscal environmental factor: This environmental factor retakes the nature of Nigerian economy and its effect on Local Governments budget for human resource management. The economy determines to a large extent the negative or positive advancement of the human resource management activities. This was noted during the economic recession in 2016-2017, when Local Governments were poorly funded and could not sponsor staff for seminars and conferences, and most staff resisted posting on account of Council's inability to pay first 28 days posting allowances to staff involved in inter-council posting. The Councils fund improved relatively in 2018 as the recession became over, and Council approval for staff training improved.

Technological Factor: The technological factor is discussed in two perspectives. Firstly, that change and advancement in technology leads to automation of the administrative system. This involves computerization of the offices with modern technological equipment such as personal computer (PC) and other electronics. With the new equipment, productivity is high with less manpower. The effect is that those who are not computer literate will lose their job, and the local government will be forced to reduce her workforce and increase the equipment. Secondly, the introduction of Information and Communication Technology in the offices has led to emergence of Human Resource Information System (HRIS) to facilitate human resource planning, development and utilization in the Council. Negatively, Deadrick, Lukaszeweki\& Johnson 
(2015) explained that advancement in technology creates artificial communication distance among staff, limits interpersonal interaction etc, in the organization, which affect human resource management. Positively, Walker (1982) states that the new technology encourages easy data collation and analysis on staff matters, quick information dissemination among staff and between staff and management, and durable data storage facility in the organization. This affects manpower planning, training, deployment, utilization and retirement in the local governments.

Political Factor: Nigeria federal system creates an imbalance among the three tiers of government, with the Local Government paying the highest price. The provisions of 1999 Constitution empower the State Governments to control the Local Governments in its domain. The State Government control the Local Government administrative personnel through the Local Government Service Commission (whose officers are purely state appointees), and Local Government funds through Joint Account and Allocation Committee (JAAC). With the multi-party system, the politics of ruling and opposition political party play out in the appointment of Local Government functionaries. The governor use the Commission to appoint faithful and loyal party members in the Local Government service into the positions of Heads of Local Government Administration, Head of Personnel Management, Council Treasurers and other Directors. This appointment is no longer on merit but on political party influence and patronage. Same is applicable to staff recruitment, training, posting, utilisation and retirement in the local governments. .

Legal Factor: The legal framework in Nigeria in regulating the activities of Nigerian workers including those of Local 
Wilson: Environmental Factors and Human Resource Management in Local Government Administration in Nigeria

Governments affect the human resource management in Local Governments. Nigerian constitution provides the platform for Councils to function, and literally affects the human resource management in the Councils. Labour law provides for the rights of workers in the workplace, worker to worker relations, and worker - management relations in the organization. The 2004 Labour Law clearly democratized and liberalized the labour movement, giving room for multiple industrial unions and workers free choice of union to belong in the industry. This results in emergence of multiple unions in the same industry and conflict of the unions over the right of unionism of the workers, culminating in constant industrial actions in such industry. In 2010, the conflict between Agriculture and Allied Workers Union of Nigeria and NULGE over right of unionism of Agriculture Department workers in Local Governments gave rise to industrial action in some Councils, and severally, Medical and Health Workers Union of Nigeria (M\&HWUN) and Nigeria Union of Local Government Employees (NULGE) dispute over jurisdiction on workers of Community Health Department. The inter unions conflict affects staff management relations and productivity in the Local Government service..

Physical Factor: This environmental factor involves natural occurrences such as topography of the Local Government, location of the Local Government, and weather. Some Local Governments within the Niger Delta region are located in the core riverine areas such as Bomadi and Burutu in Delta State, Bonny, Opobo/Nkoro, and Andoni in River State, Bakassi in Cross River State, Brass in Bayelsa State etc. During rainy season, workers attendance to work and participation in training programmes in such Councils are 
affected negatively due to high tide and turbulence of the seas, as well as swampy and flooding nature of the Councils. Staff resist posting to such Councils due to its location. In the Northern part of the country, the dusty atmosphere and heat from the high pressure of sun affect some staff, particularly those with health challenges from participating in Council programmes and training, leading to job avoidance and poor productivity.

Social Factor: This factor explains personal relationship with one another in the service. The religious and family bonds affects human resource management activities in the Councils, as some workers are appointed, posted and assigned duties due to their religious and / or family relationship with the Local Government Service Commission officials and /or Council functionaries. Alao, Ajike \& Ibrahim (2016) added that socio-religious influence on Local Government administration is enormous in Nigeria, particularly as it polarizes the staff along religious divide thereby affecting thereby their productivity in the Council. The effect is that sometimes the wrong caliber of staff is recruited into the local government service leading to poor performance of such staff.

\section{Recommendations}

Upon the above findings, the study made the following recommendations.

$>$ Financial autonomy of the Local Government will go a long way to enhance the Council capacity to carry out effective human resource training and development programme, thereby reducing human resource management challenges in the Council.

$>$ Election and appointment of Council officials should be based on competence, rather than political patronage and socio- 
religious influence. This will provide adequate caliber of personnel to man Local Government personnel issues.

$>$ There should be regular staff orientation and education on work ethics, value and need for effective compliance to workplace rules to enable Local Government workers abide willing to the Council policies on staff matters.

$>$ The activities of Local Government Service Commission should be guided by the prevailing laws establishing it to enable the Commission effectively carry out the necessary human resource management policies in the Councils.

$>$ The relations and interplay of power among the various labour unions in the Local Government should be clearly defined by the enabling labour laws to determine the unions' jurisdictional scope as to reduce industrial conflict and enhance human resource management activities in the Councils.

$>$ Staff data should be properly planned and managed to ensure its usefulness in staff management in the Council.

\section{Conclusion}

The study established various internal and external environmental factors affecting human resource management activities in the Local Government service. Local Government as a system shows that the operating units interact and interdependent on each other to function adequately. The Administration Department needs to interact with other Departments/sectors within the Local Government and beyond. Such interaction and interdependence creates and/or reinforces the environmental factors, with some factors having negative influence and others having positive influence on human resource management in the Councils. Imperatively, the study indicates that environmental factors have 
significant effects on human resource management. We therefore recommend that the various factors affecting human resource management should be addressed and redefined to achieve effectiveness and efficiency in the Local Government system. This will provoke further research on the prospects of human resource management in Nigerian Local Governments.

\section{Goddey Wilson}

Department of Political Science Ignatius Ajuru University of Education, Port Harcourt Rivers State, Nigeria goddey.wilson@iaue.edu.ng 
Wilson: Environmental Factors and Human Resource Management in Local Government Administration in Nigeria

\section{References}

Agunyai, S.C. (2015) Manpower development, capacity building and service delivery in Ife -East Local Government Area, Osun State, Nigeria. Journal of Public Administration and Policy Research 7(1) 1-14.

Alao, D. O., Ajike, C. A. \& Ibrahim, M. N. (2016) Environmental factors and Local Government administration in Nigeria: A study of Ede North and Ede South Local Government, Osun State, Nigeria, 1999 - 2014. Kuwait Chapter of Ariabian Journal of Business and Management Review 5 (7) 28 - 42 .

Baikie A (2002). Recurrent Issues in Nigeria Education. Zaria: TamazaPublishing Company.

Bertalanffy, V. L. (1950) An outline of General System Theory. British Journal for the Philosophy of Science 1(2). 135 165.

Collings, D.G. \& Wood, G. (2009) Human resource management : A critical approach. In D. G. Collings\& G. Wood ( Eds) Human Resource Management : A Critical Approach . London : Routledge. 1-16

Deadrick, D.L., Lukaszeweki, K.M., \& Johnson, R. (2015) The influence of technology on the future of human resource management. Human Resource Management Review 25(2), $216-231$.

Giddens, A. (1986) Capitalism and Modern Social Theory. Cambridge: Cambridge University Press.

Graffin, R. (2007) Principles of Management. Buston : Houghton Mifflin Company.

Johnason, P. (2009) HRM in changing organizational contexts. In

D. G. Collings\& G. Wood ( Eds) Human Resource 
Management : A Critical Approach. London: Routledge. 19-37.

Katz, D. \& Kahn, R. L. (1966) The social phycology of organization. New York : John Willy \& Sons

Mayo, E. (1945) Hawthorne and the Western Electric Company .www.google.com Retrieved on $20^{\text {th }}$ June, 2018.

Mele, C., Pels.,\&Polese, F. (2010) A brief review of system theories and their managerial applications. Service Science $2(1 \& 2)$ 126-135.

Merkle, J. A. ( 1980) Management and Ideology. California : University of California Press

Nabaho, L. \& Kiiza, A. (2018) Human resource management in Local Governments : An analysis of recruitment and selection practice in Uganda. The Journal of Africa \& Asia Local Government Studies. 6(1) 1 -14.

Ojo, F. (1997) Human Resource Management : Theory and Practice. Lagos :Panaf Publishing Inc.

Ojo, F. (1998) Personnel Management: Theories and Issues .Lagos :Panaf Publishing Inc.

Okolie, F.C. (2000) Developing appropriate manpower plans in the Local Government System. In F. O. Onah (ed) Strategic Manpower Planning and Development.

Nsukka: Fulladu Publishing Company. 35 - 44.

Omodia .M (2009). Manpower Development in Nigeria:

Conceptual and Methodological Perspectives. Journal of Social Sciences. 18(2): 113-117.

Onah, F. O. (2015) Human Resource Management $\left(4^{\text {th }} E d\right)$.Enugu : University of Nigeria Press Ltd.

Onah, R. (2000) Assessing the manpower planning environment in Nigeria. In F. O. Onah (Ed) Strategic Manpower Planning and Development. :Fulladu Publishing Company. 
Wilson: Environmental Factors and Human Resource Management in Local Government Administration in Nigeria

Vincent, C. \& Stephen, C. (2015) Local Government capacity building and development: Lessons, challenges and opportunities. Journal of Political Science \& Public Affairs 3(1) $1-5$.

Walker, A.J.(1982) HRIS Development. New York : Van Nostrand Reinhold.

Wilson, G. (2013) The politics of Local Government reforms and democratic governance in Nigerian Local Governments. Developing Country Studies 3(1) $136-143$.

Wilson, G. (2015) The causes, effects and management of industrial conflict in Local Governments of Delta State, 2008 - 2014. International Journal of Research in Arts and Social Sciences 8(2) $44-55$. 